\title{
Diversion, Conferencing, and Extrajudicial MEASURES FOR ADOLESCENT OFFENDERS
}

\author{
NichOlas BaLA
}

In responding to youth crime, Canada makes disproportionate use of courts and custodial sentences, while other countries divert more youth from the formal justice system and make greater use of community-based responses. This article surveys diversion from the youth courts under the different youth justice regimes that have existed in Canada, including informal and formal screening, police and Crown cautions, and use of youth justice committees and conferencing. The newly enacted Youth Criminal Justice Act is intended to encourage greater use of these diversionary "extrajudicial measures, "and more use of a "restorative justice" approach to cases. A major limitation is that these provisions are permissive, and create no new legal rights for youths and impose no new obligations on governments. It will be up to provincial governments to decide whether to allow police. prosecutors and local program operators to actually implement these provisions. Further, depending on how these provisions are implemented, there are legitimate concerns about the potential for these informal responses to abuse the rights of youths or ignore the needs of victims. There should be both monitoring of the implementation of these provisions and research to determine how effective they are at reducing offending, and meeting the needs of victims, offenders and communities.
Dans le domaine de la criminalité che: les jeunes, le Canada fait un usage disproportionne des tribunaux et des sentences de garde, alors que d'autres pays dirigent plutôt la jeunesse vers les programmes communautaires au lieu des tribunaux. Cet aricle porte sur celte démarche sous les divers régimes de justice qui ont existé au Canada, y compris la sélection officielle et non officielle. la prudence de la police et de la Couronne et le recours aux comités et conférences sur la justice pour les adolescents. Le but de la nouvelle Loi sur le système de justice pénale pour les adolescents consiste à encourager une plus grande utilisation des mesures extrajudiciaires et un plus grand recours à la "justice réparatrice" à l'égard de ces infractions. Le fait que ces dispositions sont permissives et ne créent pas de nouveaux droits légaux pour les jeunes sans imposer de nouvelles obligations atux gouvernements représente une importante limitation. Il incombera aux gouvernements provinciaux de décider dans quelle mesure il faut permettre à la police, aux procureurs et aux exploitants de programmes locaux de vraiment exécuter ces dispositions. De plus. dépendant de la manière dans laquelle ces dispositions sont exécutées, il y a lieu de s'inquiéter de la mesure dans laquelle les réponses officieuses représentent un abus des droits des jeunes ou ignorent les besoins des victimes. Ces dispositions devraient faire l'objet d'un suivi et d'une recherche quant à leur efficacitè à réduire les infractions el à répondre aux besoins des victimes, des délinquants et des communautés.

\section{TABLE OF CONTENTS}

I. INTRODUCTION: THE CONTEXT FOR INCREASING

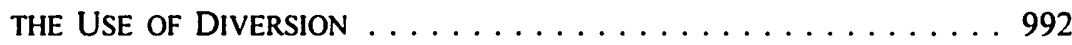

II. THE HISTORY AND RATIONALE FOR JUVENILE

DIVERSION IN CANADA . . . . . . . . . . . . . . . . 994

III. ALTERNATIVE MEASURES UNDER THE YOUNG OFFENDERS ACT _. 997

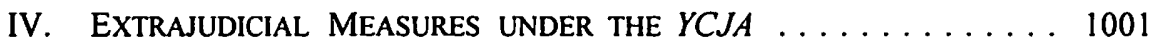

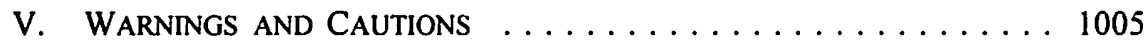

A. Police Warnings and Cautions: Sections 6 And $7 \ldots 1005$

Professor, Faculty of Law, Queen's University. Portions of this article are a revised version of $\mathrm{N}$.

Bala, Youth Criminal Justice Law (Toronto: Irwin Law, 2003), c. 5. 


\section{B. CROWN CAUTIONS AND SCREENING:}

SECTIONS 8 and $23 \ldots \ldots \ldots \ldots . \ldots . \ldots . \ldots . \ldots 9$

C. SUBSEQUENT USE OF A CAUTION OR WARNING:

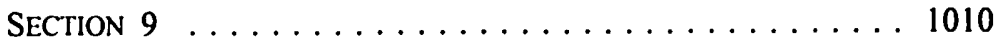

VI. YoUTH JUSTICE COMMITTEES: SECTION $18 \ldots \ldots \ldots \ldots \ldots 1011$

VII. YOUTH JUSTICE CONFERENCES: SECTIONS 19 AND $41 \ldots \ldots \ldots 1012$

VIII. EXTRAJUdicial SANCTIONS UNDER THE $Y C J A \ldots \ldots \ldots \ldots 1017$

IX. ROLE AND RIGHTS OF YouTHS $\ldots \ldots \ldots \ldots \ldots \ldots \ldots \ldots 1022$

X. CONSEquences of Participation $\mathrm{N}$

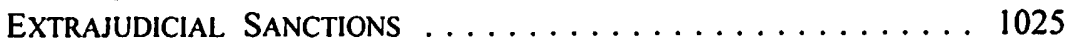

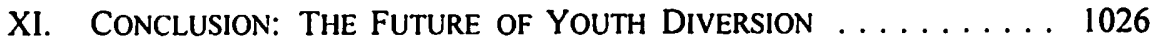

\section{INTROduction: The CONTEXT FOR INCREASING THE USE OF DIVERSION}

Although levels of youth crime in Canada actually seemed to be slowly falling or at worst had plateaued' during the decade prior to the coming into force of the Youth Criminal Justice Act, there was, somewhat paradoxically, a dramatic increase in concern among politicians and members of the public about youth crime. Reflecting and perhaps fanning the flames of public concern, conservative politicians in federal opposition parties and provincial governments were demanding a "get tough" approach to youth crime. At the same time, academic critics and youth justice system professionals, including many judges, ${ }^{2}$ were expressing concerns that Canada was making far too much use of courts and custody under the Young Offenders Act, and that many cases should be diverted from the formal youth justice system.

The dominant public rhetoric of the Liberal government at the time of the introduction of its Strategy for Youth Justice Renewal in 1998, which resulted in the enactment of the Youth Criminal Justice Act in 2002, was about the need "to deal more firmly and effectively with violent and repeat young offenders." ${ }^{3}$ There are provisions in the new Act that facilitate the imposition of adult sentences and the publication of identifying information about serious violent offenders.

Probably the most significant parts of the YCJA, however, do not deal with the relatively small number of serious violent offenders, but rather deal with the large majority of offenders who commit non-violent offences, or violent offences that do not involve serious injury. These are provisions that are intended to reduce the use of courts and to increase community-based responses to youth crime, while reducing Canada's "over-reliance on incarceration" for young offenders. ${ }^{4}$

P. de Souza, "Youth Court Statistics, 2000/01" (2002) 22:3 Juristat.

A.N. Doob, Youth Court Judges' Views of the Youth Justice System: The Results of a Survey (Toronto: Centre of Criminology, University of Toronto, 2001) reported that in a national survey of youth court judges, 54 percent said that over half of the cases they saw would be better dealt with outside the youth court system.

A. McLellan, "Minister Announces Youth Justice Strategy" (12 May 1998), online: <canada.justice.gc.ca/en/news/nr/1998/yoa.html> (last modified: 20 December 2002).

Youth Criminal Justice Act, S.C. 2002, c. 1 (royal assent 19 February 2002, in force 1 April 2003), Preamble [hereinafter $Y C J A$ ]. 
While the primary legal response to serious youthful offending should be through the court system, there are many youths who should be "diverted" from the formal justice system and dealt with in a more informal fashion. Alternatives to formal criminal responses are appropriate for adults as well, but these informal responses are especially worthy of consideration for adolescents who break the law, reflecting the principle that "consistent with [their] greater dependency and ... their reduced level of maturity," youths should have more limited accountability than adults. ${ }^{5}$ For many adolescent offenders, some form of non-judicial response is sufficient to hold the youth accountable and deter any further offending.

Under the Juvenile Delinquents Act, which was in effect from 1908 to 1984, informal responses to youth crime were very common, with school officials, police and probation officers using court as a last resort. The Young Offenders Act did not require more use of court and formal responses to youth crime. Indeed the Declaration of Principle of the $Y O A$ made explicit reference to the value of "taking no measures" or using alternative measures for youthful offenders. ${ }^{6}$ Nevertheless, after the coming into force of the YOA in 1984, there was a dramatic increase in the use of formal court-based responses to youth crime. By the late 1990 s there was increasing recognition of the limitations and costs of a formal response to youth crime, and of the desirability of diverting more young offenders away from the court system. The $Y C J A$ is clearly intended to substantially decrease the use of formal court-based responses to youth crime, while increasing informal community-based responses to youth offending. This move towards the increased use of community-based responses is consistent with a growing interest in "restorative justice" in Canada, and with developments in other countries.

This article discusses the provisions of the $Y C J A$ that are intended to increase the use of informal responses to youth crime; responses that divert adolescent offenders from the courts - including what the $Y C J A$ refers to as "extrajudicial measures" and "conferencing." The enactment of these provisions is on the whole a desirable development. Although there is a lack of good research to conclusively establish the superiority of informal responses to youth crime in terms of reducing recidivism, it is clear that for a significant range of cases informal responses are no worse than formal court-based responses for achieving accountability and protecting society, and there is the prospect that these approaches may increase the engagement of victims and offenders in the justice system and perhaps even reduce recidivism. These informal responses certainly have the potential to be more expeditious and less expensive than the courts.

A major limitation of these provisions of the $Y C J A$ is that they are essentially permissive; they create no new legal rights for youths and impose no new obligations on governments. It will be up to provincial and territorial governments to decide whether to allow police, prosecutors and local program operators to actually implement these provisions. Further, depending on how these provisions are implemented, there

Ibid., s. 3(1)(b)(ii).

Young Offenders Act, R.S.C. 1985, c. Y-1, enacted as S.C. 1980-81-82-83, c. 110. s. 3(1)(d) [hereinafter $Y O A$ ]. 
are legitimate concerns about the potential for these informal responses to abuse the rights of youths or ignore the needs of victims. There is a clear need both for the monitoring of the implementation of these provisions and for research to determine how effective they are at reducing offending and at meeting the needs of victims, offenders, and communities.

\section{The History and Rationale for Juvenile Diversion in Canada}

Under the Juvenile Delinquents $A c t,{ }^{7}$ alternatives to formal charging were widely employed. Most frequently, diversion was informal: although the $J D A$ had no express provisions dealing with diversion, it was a frequent practice for police who apprehended juveniles for minor offences to release them after talking to the youths, and perhaps to the parents, to warn them that if there was further offending, their cases would be taken to juvenile court. It was also more common under the $J D A$ than at present for school officials, parents and other adults who became aware of youthful offending to deal with the behaviour informally, without calling the police, perhaps by resorting to corporal punishment.

By the 1970s, the first formal diversion programs were being established by various social agencies in Canada and other countries. Police or prosecutors were starting to send youths to these community-based programs rather than to juvenile court. One of the rationales offered for the first formal juvenile diversion programs in the early $1970 \mathrm{~s}$ was a sociological doctrine known as "labelling theory." This theory is that youths who are labelled or referred to by police and other authority figures as "delinquents" will come to think of themselves as "offenders." It is argued that such labelling will contribute to future offending or "secondary deviance." Proponents of this theory argue that some youths may be unnecessarily harmed by being labelled as "young offenders" through the formal court process, and that they may be less likely to reoffend if they are diverted to a relatively informal process which does not involve as significant labelling. Labelling theory has never been clearly demonstrated to reflect reality, and empirical research is at best equivocal about whether merely identifying and describing a youth who has been apprehended as an "offender" actually increases the likelihood of reoffending.

The term "restorative justice" is increasingly being used to characterize responses to offending that involve the victim, the offender, family members, and community members in a process of discussion about the offence and its effects on the victim and the community, and the joint development of a plan to provide compensation to the victim and to help prevent recurrence of offending behaviour. Restorative justice is distinguished from the retributive principles of the conventional criminal justice model by its focus on restoring relationships between the offender and the victim, and between the offender and the community. While courts can make use of restorative justice

Juvenile Delinguents Act, enacted as S.C. 1908, c. 40; subject to minor amendments over the years, finally as Juvenile Delinquents Act, R.S.C. 1970, c. J-3 [hereinafter JDA].

See, e.g., S. Moyer, Diversion from the Juvenile Justice System and its Impact on Children: A Review of the Literature (Ottawa: Minister of Supply and Services, 1980) at 67-73. 
principles in dealing with offenders, a range of diversion programs are especially wellsuited to applying restorative justice principles. ${ }^{9}$

There have recently been a few studies from Australia and New Zealand which report that some types of diversion programs may actually reduce recidivism, and in particular that programs that involve victims and offenders and have some "restorative justice" components may have lower recidivism rates than court-based responses for comparable groups of young offenders. ${ }^{10}$

There is only one reported Canadian study that compares the outcomes for youths randomly assigned to court with the outcomes for youths assigned to a community diversion program involving an informal meeting with offenders, parents and victims." That study, of the Kingston, Ontario diversion program, reported no significant difference between use of court and use of a diversion program in terms of future recidivism, though victims and youth reported that they were more engaged in the informal diversion process and cases were resolved more quickly through diversion. Another Canadian study of police decisions to charge found that youths who were not charged but dealt with by police by means of an informal caution were no more likely to reoffend than a comparable group of youths who were charged and sent to court. ${ }^{12}$

See, e.g., G. Bazemore \& L. Walgrave, eds., Restorative Juvenile Justice: Repairing the Harm of Youth Crime (Monsey: Criminal Justice Press/Willow Tree, 1999); B. Archibald, "A Comprehensive Canadian Approach to Restorative Justice" in D. Stuart, R.J. Delisle \& A. Manson, eds., Towards A Clear and Just Criminal Law: A Criminal Reports Forum (Scarborough: Carswell, 1999) at 520; J. Braithwaite, "Restorative Justice and Social Justice" (2000) 63 Sask. L. Rev. 185; and R. Prashaw, "Restorative Justice: Lessons in Empathy and Connecting People" (2001) 20 Can. J. Community Ment. Health 23.

In R. v. Gladue, [1999] I S.C.R. 688, Cory and lacobucci JJ. wrote, at 726:

In general terms, restorative justice may be described as an approach to remedying crime in which it is understood that all things are interrelated and that crime disrupts the harmony which existed prior to its occurrence, or at least which it is felt should exist. The appropriateness of a particular sanction is largely determined by the needs of the victims, and the community, as well as the offender. The focus is on the human beings closely affected by the crime.

10 See, e.g., A. Morris \& G. Maxwell, "Restorative Conferencing" in G. Bazemore \& M. Schiff, eds., Restorative Community Justice: Repairing Harm and Transforming Communities (Cincinnati: Anderson Publishing, 2001) 173-97; and K. Daly, "Conferencing in Australia and New Zealand: Variations, Research Findings and Prospects" in A. Morris \& G. Maxwell, eds., Restorative Justice for Juveniles: Conferencing. Mediation and Circles (Oxford: Hart Publishing, 2001) 59-83. M.E. Morton \& W.G. West, "An Experiment in Diversion by a Citizen Committee" in R. Corrado, M. LeBlanc \& J. Trépanier, Current Issues in Juvenile Justice (Toronto: Butterworths, 1983) 20316. There is, however. significant empirical support for the proposition that, even taking into account prior offending and the seriousness of the offence, a court-based response which places the youth in custody disrupts relationships with parents and results in the youth being seen as a relatively serious offender, which does increase the likelihood of recidivism: see E.A. Stewart, et al., "Beyond the Interactional Relationship Between Delinquency and Parenting Practices: The Contribution of Legal Sanctions" (2002) 39 J. Res. in Crime \& Delinquency 36.

12 See K.J. Kijewski, “The Effect of the Decision to Charge Upon Subsequent Delinquent Behaviour" (1983) 25 Can. J. Crim. 201. 
Thus there are no Canadian studies to support "labelling" theory, that is, which demonstrate that using an informal community-based non-court response as opposed to youth court charging actually reduces recidivism. It is clear, however, from research in Canada and elsewhere, that in situations where it has been employed, the use of diversion does not increase the likelihood of a youth reoffending and that most youths who are sent to these programs do not reoffend.

The fact that diversion does not, in itself, necessarily reduce reoffending does not mean that diversion programs are without value. Diversion programs have the potential to resolve a case in a way that is more expeditious and less expensive for society than a court-based response. Further, in comparison to the formality and adversarial nature of youth justice court - a forum that tends to preclude open discussion between the individuals concerned with a crime - a properly designed diversion program can offer youths, parents, and victims an opportunity to actively engage in achieving a resolution for the situation caused by the offending which may prove more satisfactory to all involved. There may also be an important role for members of the community in diversion programs. Such community involvement may be especially important for Aboriginal communities, although it may be appropriate in other communities as well.

Diversionary responses to youth crime based on labelling theory and restorative justice principles have not been conclusively proven to reduce recidivism, but there is the prospect that some types of diversion programs can reduce reoffending among some youths. Many different models of diversion are being tried in Canada. Some diversion programs provide responses that are quite similar to those used by the courts, albeit without being imposed after a judicial process, and these are likely to have similar recidivism rates as court-based responses. There are now, however, some programs that offer responses to offending that are not available through the conventional youth court system. Innovative programs allow for the interaction of victims, families of offenders, and community members with the youth in a way that is not possible in court. Some programs may have access to counselling resources and an ability to engage the youth in a way that is not possible in the court system. These innovative programs need to be assessed to determine whether they actually reduce recidivism.

Diversion is an important potential response to youthful offending, and the $Y C J A$ has a number of provisions that are intended to encourage a range of diversionary responses, or "extrajudicial measures" as they are known under the $Y C J A$. As well as enacting provisions of the $Y C J A$ that encourage diversion, the federal government is providing some additional funding to support community-based responses to youth crime.

Diversion, which has been underused in Canada, should be encouraged. Even so, there remain legitimate concerns about its potential misuse that need to be addressed, such as the possibility that diversion may jeopardize the rights of young persons or victims, or may fail to take sufficient account of the interests of society. There is also the potential for diversion to be applied in a discriminatory fashion, with youths from certain disadvantaged or socially marginalized backgrounds being less likely to be dealt with outside of the court system. Similarly, the efficacy of some restorative justice 
programs for reducing recidivism among youthful offenders has been questioned. Some researchers believe restorative justice processes have been shown to greatly reduce recidivism. ${ }^{13}$ Others, however, maintain that the empirical research does not support such optimistic conclusions and have expressed concerns that family or group conferencing, for example, can have a negative impact on victims of youth crime. ${ }^{14}$ There are also concerns about the potential for inconsistency, lack of proportionality, and unfairness in how offenders are treated. ${ }^{15}$ These concerns should be kept in mind when designing, implementing, and evaluating such programs.

\section{Alternative Measures Under the Young OfFenders ACT}

The drafters of the $Y O A$ wanted to encourage the practice of diversion as it developed under the $J D A$, although they also wanted to regulate certain aspects of it to prevent overly intrusive responses. The Declaration of Principle in s. 3(1)(d) of the YOA expressly recognized that, "where it is not inconsistent with the protection of society, taking no measures or taking measures other than judicial proceedings [under the $Y O A$ ] should be considered for dealing with young persons who have committed offences." Section 4 of the $Y O A$ created a legislative framework for alternative measures to deal with young persons who were believed to have committed criminal offences.

Alternative measures were a form of diversion from the court process which allowed a youth to be dealt with in a relatively expeditious, informal fashion, and enabled a youth to avoid a formal youth court record. Alternative measures were generally used for youths who committed the least serious offences and who did not have a history of offending. There was, however, substantial variation in how s. 4 was applied, with some provinces taking a more expansive approach and permitting youths facing more serious charges and with a prior record of offending to be considered for alternative measures.

The drafters of the $Y O A$ intended to increase the use of various informal alternatives to the formal youth justice system. It is now clear, however, that after the YOA came into force, fewer young offenders were dealt with by means of screening or diversion than was the case under the more informal $J D A$. The use of court-based responses to youth crime actually significantly increased under the $Y O A$. The reasons for the increase in the use of formal responses to youth crime under the $Y O A$ are complex, and this general trend to make greater use of courts rather than informal responses to youth crime was not uniform across Canada.

It is significant that in some provinces, most notably Quebec, the introduction of the $Y O A$ was not accompanied by an increase in use of court-based responses to youth

13 See, e.g., Braithwaite, supra note 9.

it See, e.g., K. Haines, "Some Principled Objections to a Restorative Justice Approach to Working with Juvenile Offenders" in L. Walgrave, ed., Restorative Justice for Juveniles: Potentialities, Risks, and Problems for Research (Leuven: Leuven University Press, 1998) at 93-113.

t5 See, e.g., A. Ashworth, "Is Restorative Justice the Way Forward for Criminal Justice?" (2001) 54 Curr. Leg. Probs. 347. 
crime. In Quebec, the government established programs and policies that encouraged police and Crown prosecutors to divert less serious offenders from the youth court system to either informal community-based alternatives or to the child-welfare system. Under the YOA, Quebec had the lowest rate of use of youth court in Canada. ${ }^{16}$ In other provinces, however, the introduction of the YOA was accompanied by a phenomenon known as "net widening." Alternative measures programs were established, but frequently the police did not actually divert youths who would otherwise have been charged in court from the court system to these programs. Rather, youth who committed minor offences which under the $J D A$ would have resulted in an informal caution by the police were sent to the new programs, while charge rates in youth court remained the same or actually increased.

The YOA came into force about the same time as the Charter, ${ }^{17}$ and together these two legal instruments created a more formal and rights-oriented response for police and courts to follow in dealing with youth offending. The YOA did not preclude the use of informal responses. Indeed, some of the statements in the Declaration of Principle actually encouraged diversionary responses. Nonetheless, many police and prosecutors were influenced by the more formal approach to youth justice reflected in the YOA to move away from informal responses to youth crime and toward ones focused on courts.

Perhaps more significantly, the increased use of court following the enactment of the YOA may in part have been a police response to the growing public pressure to "do something" about youth crime. Arresting youths who in the past might have been dealt with informally was one police response to community demands to "get tough" with young offenders. In some provinces the use of court-based responses was also encouraged by provincial policies that restricted the use of alternative measures or, for a time, precluded it altogether.

Under the $J D A$, the issue of juvenile diversion received little or no attention from most provincial governments. Local programs, police forces, and Crown prosecutors could exercise their discretion to divert quite a broad range of cases. When the YOA came into force, provincial governments began to develop formal policies about referring youths to alternative measures programs - policies that were often more restrictive than the practices of police, prosecutors, and operators of diversion programs under the $J D A$. The effect of these policies was to encourage a more formal response to youth offending.

The Canadian Centre for Justice Statistics reported an annual youth court charge rate in 1999-2000 of 196 per 10,000 youths in Quebec, compared to a national rate of 417 , with Ontario having a rate of 428 and Manitoba having a rate of 700: M. Sudworth \& P. de Souza, "Youth Court Statistics, 1999/00" (2001) 21:3 Juristat. Conversely, in 2000-2001, the rate of use of alternative measures per 10,000 youth was only 59 in Ontario, but 169 in Quebec and 183 in Alberta: J. Marinelli, "Youth Custody and Community Services in Canada, 2000-2001" (2002) 22:8 Juristat at 4.

17 Canadian Charter of Rights and Freedoms, Part I of the Constitution Act, 1982, being Schedule B to the Canada Act 1982 (U.K.), 1982, c. 11 [hereinafter Charter]. 
A narrow approach to the alternative measures provisions of the $Y O A$ was most apparent in Ontario. When the YOA came into force, Ontario's opposition to alternative measures reflected a general political resistance by the provincial government to the federally enacted statute. With an attitude that critics referred to as a provincial failure to adopt "the spirit of the law,"18 the Ontario government argued that the research into the effectiveness of diversion in terms of reducing recidivism was "ambiguous and conflicting," and expressed concerns about the potential for abuse of the rights of youths in these programs as well as about "net widening." 19 Ontario initially provided no new funding for the establishment of diversion programs, and refused to implement s. 4 of the $Y O A$. Section 4(1)(a) provided that "Alternative measures may be used ... only if ... the measures are part of a program authorized" ${ }^{20}$ by the provincial government, and the Ontario government decided not to formally authorize any programs. $^{21}$

Since all the other provinces and territories established programs to give adolescents access to alternative measures, it is not surprising that the decision of Ontario not to implement s. 4 of the $Y O A$ was challenged as a violation of the principle of "equality under the law" guaranteed by s. 15 of the Charter. In 1988, in $R$. v. S.(S.), "22 the Ontario Court of Appeal held that the absence of such programs in Ontario constituted a "denial of equal benefit" and protection of the law on the basis of province of residence, and hence violated s. 15 of the Charter. The government of Ontario responded to the Court of Appeal decision by establishing alternative measures programs across the province, albeit on an "interim basis," but the government also appealed to the Supreme Court of Canada.

In June of 1990 the Supreme Court reversed the Ontario Court of Appeal decision in $R$. v. $S .(S.){ }^{23}$ The Supreme Court observed that s. $4(1)$ of the YOA provided that "Alternative measures may be used," ${ }^{24}$ indicating that there was a discretion granted to the provincial government as to whether to establish any of these programs. The Supreme Court held that it was constitutionally valid for Parliament to delegate authority to the provinces under s. $4(1)(a)$ to decide whether to establish alternative measures. Under Canada's federal system, it is not a violation of the Charter to have youths in one province denied access to alternative measures. Although some types of interprovincial differences in treatment under the criminal law would be unconstitutional, the Supreme Court adopted an approach that required an assessment

See K. Makin, "Ontario move on young offenders backed" Globe \& Mail (29 June 1990) A7. I. Scott, then the Attorney General of Ontario, quoted in Ontario Social Development Council. Y.O.A. Dispositions: Challenges and Choices (Toronto: Ontario Social Development Council, 1988) at 16.

YOA, supra note 6 [emphasis added].

In practice, some of the diversion programs in Ontario established before the YOA came into force in 1984 continued to operate with the co-operation of local police and prosecutors. and even with some funding from the community and social services ministry. The opposition to alternative measures in the Ontario government in the 1984-1990 period was largely centred in the Ministry of the Attorney General.

(1988), 63 C.R. (3d) 64 (Ont. C.A.).

[1990] 2 S.C.R. 254.

lbid. at 273 [emphasis in original]. 
of all the circumstances of a particular delegation of responsibility to provincial governments to determine whether there is a Charter violation. Chief Justice Dickson observed that,

diversity in the criminal law, in terms of provincial application, has been recognized ... as a means of furthering the values of federalism ... [The] question of how young people found to have committed criminal offences should be dealt with is one upon which it is legitimate for Parliament to allow for province-based distinctions.... [Benefits] derive from the adaptability of a program of alternative measures to the needs of different regions and communities. ${ }^{25}$

In a decision rendered at the same time as $R$. v. S.(S.), the Supreme Court also accepted that if provinces chose to establish alternative measures programs, they could develop their own criteria for eligibility. If a province chose to have narrower offence criteria for its alternative measures programs than other provinces, that did not render its program unconstitutional. ${ }^{26}$

Despite the Supreme Court of Canada decisions which would have allowed Ontario to have no alternative measures programs, the Ontario government continued and actually expanded its "interim" alternative measures programs. Shortly after $S$.(S.), the Supreme Court gave its decision in $R$. v. Askov, ${ }^{27}$ ruling that delays in the Ontario courts were denying accused persons - principally adults but also youths - the constitutionally guaranteed right to a trial within a reasonable time. The Askov decision placed great pressure on the Ontario government to deal with the problem of overcrowding in the court system and provided a strong impetus for moving the least serious cases out of the courts by making greater use of alternative measures programs. Accordingly, the Ontario government decided to join all other provincial governments in Canada and permanently establish alternative measures programs to relieve pressure on the courts.

Even after deciding to adopt alternative measures, Ontario maintained the most restrictive alternative measures policies in Canada. Ontario was the only province to have alternative measures policies that operated exclusively on a post-charge basis. Before a referral could be made, it was generally necessary for the youth to appear in youth court, where an initial decision about referral to alternative measures was made by the Crown prosecutor. If a youth was referred to alternative measures, the court case would be adjourned. This type of post-charge process is cumbersome and relatively intrusive for the youth and parents. Further, the offence criteria established by the Attorney General of Ontario to help determine eligibility for alternative measures were narrow, generally limiting their use to property offences under $\$ 5000$ where the youth had no prior record of offending. ${ }^{28}$ The official Ontario criteria thus excluded some quite common non-violent offences, in particular break and enter. In most other

Ontario, Alternative Measures Program: Policy \& Procedures Manual (Toronto: Queen's Printer, 1995). 
provinces a youth charged with this offence could be considered for alternative measures. As a result of its narrow policy, Ontario had the lowest rates of use of alternative measures in Canada. ${ }^{29}$

In contrast with Ontario, Quebec had the broadest criteria for the use of alternative measures, with the prosecutor having a discretion to send any charges to alternative measures and a requirement that all less serious cases were to be referred, usually on a pre-charge basis. ${ }^{30}$ In Quebec, youths could be sent to alternative measures even with a prior record of offending. As noted, because of this extensive use of alternative measures under the YOA, Quebec had the lowest rate of youth court charging in Canada.

The drafters of the YOA had hoped to encourage use of diversion programs and informal responses to youth crime, especially for less serious cases. By the middle of the 1990s, alternative measures programs were operating in all Canadian jurisdictions. However, Canada's response to youth crime was much more formal and intrusive than that of other countries. Comparative data released in 1998 indicated that in Canada only about 25 percent of youth cases with which police came into contact were diverted by the police or referred to alternative measures. In the United States the rate was 53 percent, while in Great Britain it was 57 percent. ${ }^{31}$

The YCJA is intended to bring Canada into closer conformity with other countries and encourage greater use of a range of diversionary measures by police, prosecutors, and communities. In addition to enacting the provisions of the $Y C J A$ that encourage the use of extrajudicial measures, the federal government is funding pilot programs and the preparation of education materials to assist those considering establishing such programs. However, the $Y C J A$ does not change the basic effect of the Supreme Court decision in $R$. v. S.(S.); it remains the responsibility of provincial and territorial governments to determine the extent to which they establish diversionary programs and policies.

\section{ExtRaJudicial Measures UNDER the YCJA}

The $Y C J A$ abandons the $Y O A$ terminology of "alternative measures" and adopts two new terms: "extrajudicial measures" and "extrajudicial sanctions." The broader concept of "extrajudicial measures" is defined in s. 2 of the $Y C J A$ as "measures other than judicial proceedings ... used to deal with a young person alleged to have committed an offence." Extrajudicial measures are all types of diversion, and include the exercise of police discretion not to charge as well as more formal diversion programs. Sections 4 and 5 of the $A c t$ set out general principles and objectives for the use of extrajudicial

C. Engler \& S. Crowe, "Alternative Measures in Canada, 1998-99" (2000) 20:6 Juristat.

See P. Plat, Young Offenders Law in Canada, 2d ed. (Markham: Butterworths, 1995) at 162; and N. Bala \& H. Lilles, eds., Young Offenders Service, looseleaf (Markham: Butterworths, 1984) vol. 1. 
measures and are clearly intended to encourage their use by police, prosecutors, youth workers, and community groups. Section 2 of the $Y C J A$ also refers to "extrajudicial sanctions," which is the new term for what under the $Y O A$ were called "alternative measures." Extrajudicial sanctions are one type of extrajudicial measure, the more formal type of pre-adjudication diversion schemes whose operation is governed by ss. 10,11 , and 12 of the YCJA.

Section 4 of the $Y C J A$ sets out principles that are to govern the establishment of policies and programs about extrajudicial measures, and are to be taken into account in making decisions about individual youths:

(a) extrajudicial measures are often the most appropriate and effective way to address youth crime;

(b) extrajudicial measures allow for effective and timely interventions focused on correcting offending behaviour;

(c) extrajudicial measures are presumed to be adequate to hold a young person accountable for his or her offending behaviour if the young person has committed a non-violent offence and has not previously been found guilty of an offence; and

(d) extrajudicial measures should be used if they are adequate to hold a young person accountable for his or her offending behaviour and, if the use of extrajudicial measures is consistent with the principles set out in this section, nothing in this Act precludes their use in respect of a young person who

(i) has previously been dealt with by the use of extrajudicial measures, or has previously been found guilty of an offence.

Section $4(c)$ of the $Y C J A$ creates a presumption that police and prosecutors should not respond through the laying of charges in youth justice court to youths who have no prior record of offending and are believed to have committed non-violent offences. Section 4(d) makes clear that extrajudicial measures may also be appropriate for some youths with prior records of offending, depending on the nature of the current offence, the previous record and the circumstances of the youth. Further, extrajudicial measures may be appropriate for some cases involving less serious violence, such as assaults in school which do not involve significant injury.

Encouraging the use of extrajudicial measures for those with prior police involvement is significant. In practice, under the $Y O A$ there was a strong presumption that alternative measures were only to be used once, with only 2 percent of the youth involved in alternative measures having a history of prior participation in such a program, and less than 1 percent having a prior youth court record. ${ }^{32}$ Section $4(d)$ of the $Y C J A$ recognizes that adolescents often make more than one relatively minor mistake. Taking into consideration the attitude of the victim and the youth, the seriousness and circumstances of the offence, and the likelihood of reoccurrence, it may be appropriate to give a youth more than one opportunity to avoid court. It is not clear that a youth justice court will have a more effective or even a more punitive sanction than some form of extrajudicial measure. Indeed, an appearance in court is often a less engaging experience for a youth than participation in an extrajudicial sanctions 
program, although the long-term consequences of going to court may be more serious, especially if the youth acquires a significant record of offending.

Section 5 sets out criteria that should be considered by those establishing programs and policies about the use of extrajudicial measures. This section makes clear that notions of restorative justice are an important aspect of extrajudicial measures. While responses to youth offending outside the court system are intended to be informal, they should encourage youths to take responsibility for their acts, engage with their families and communities, and repair harm done to victims. Section 5 provides as follows:

Extrajudicial measures should be designed to

(a) provide an effective and timely response to offending behaviour outside the bounds of judicial measures;

(b) encourage young persons to acknowledge and repair the harm caused to the victim and the community;

(c) encourage families of young persons - including extended families where appropriate - and the community to become involved in the design and implementation of those measures;

(d) provide an opportunity for victims to participate in decisions related to the measures selected and to receive reparation; and

(e) respect the rights and freedoms of young persons and be proportionate to the seriousness of the offence.

While ss. 4 and 5 encourage the use of extrajudicial measures, they do not give youth the legal right to be dealt with outside the court system. It is clear that the YCJA is not intended to change the effect of judicial precedents rendered under the $Y O A$ which held that federal legislation which encourages use of informal methods of responding to youth crime do not give any individual youth the legal right to be dealt with outside the court system. It is the police and prosecutors who decide whether a youth will be charged and taken to court, perhaps acting with the advice of probation officers or community agencies and taking account of the views of victims. It remains a matter of provincial or territorial government policy, as implemented by police officers and Crown prosecutors exercising their professional discretion, whether a youth receives the benefit of extrajudicial measures.

After the $Y O A$ came into force in 1984, there were some youth court judges who believed that the judiciary had a right - and perhaps even an obligation - to refer cases to alternative measures which they did not consider suitable for prosecution in the courts. ${ }^{33}$ However, in a number of Supreme Court decisions it has been held that the prosecutor and police have the discretion to refer cases to alternative measures, and that this discretion is not reviewable by the courts. ${ }^{34}$ In its 1992 decision in $R$. v. T. $(V .)^{35}$ the Supreme Court of Canada considered a case in which a fourteen-year-old girl who was living in a group home pursuant to child welfare legislation had been charged with mischief, assault, and uttering threats as a result of a dinner-time altercation. This was 
a situation that a parent would likely have resolved without calling the police. It appears that charges were laid only because a police officer had happened to come to the group home that evening on an unrelated matter.

The British Columbia Court of Appeal considered the effect of s. 3(1)(d) of the YOA, which provided that "where it is not inconsistent with the protection of society, taking no measures or taking measures other than judicial proceedings ... should be considered for dealing with young persons who have committed offences." The Court held that under s. 3(1)(d) of the YOA the prosecuting authorities were required to "consider" whether to use measures other than court and, if they failed to do so, a youth court judge had "ultimate responsibility" for a case and could dismiss the charges. However, the Supreme Court of Canada reversed the decision of the Court of Appeal, ruling that, except in cases of a clear "abuse of process," a judge has no discretion as to whether charges should be laid or dealt with by a court. The Supreme Court held that Crown prosecutors and the police are the appropriate officials to exercise authority under $\mathbf{s}$. $3(1)$ (d) of the $Y O A$ and refer a case to alternative measures or decide that a prosecution is appropriate. ${ }^{36}$

While an adult advocate for a youth, whether a lawyer, a parent or a social worker, can sometimes play a useful role in informally communicating with the prosecutor or police about why a youth should be diverted, the exercise of discretion by the police and prosecutor is not reviewable by a court. There was no obligation under the YOA to give a youth any sort of notice that consideration was being given to referring a case to alternative measures. Nor was there an obligation to conduct any sort of a hearing to decide whether a youth would be diverted from court. ${ }^{37}$ It has been held by youth court judges that if a youth had been charged for a relatively minor offence that the judge feels should have been dealt with outside the courts, the appropriate response is at the sentencing stage, where an absolute discharge might be appropriate. ${ }^{38}$

The statements of principle in the $Y C J A$ that are intended to encourage the use of extrajudicial measures are more detailed than those found in the YOA. They do not, however, reverse the effect of the Supreme Court of Canada decision in R. v. T.(V.), which denies the existence of a legally enforceable right to be dealt with outside the court system. ${ }^{39}$ There is only a narrow judicial power to dismiss charges that should have been dealt with by way of extrajudicial measures if there has been an abuse of process. Such an abuse might arise, for example, if there were a police or prosecutorial decision about the use of extrajudicial sanctions that discriminated on the basis of

3. Ibid.

${ }^{7} \quad$ W. (T.) v. Smith (1986), 45 Sask. R. 191 (Q.B.); R. v. B.(G.) (December 1994), Hudson 94A0211(Y.S.C.) [unreported] [summarized (1995), 26 W.C.B. (2d) 48].

ix R. v. T.(G.) (1987), 57 C.R. (3d) 388 (Alta. Prov. Ct. (Youth Div.)).

"R. v. T.(V.), supra note 35. YCJA, supra note 4, ss. 6(2) and 10(6), discussed below, make clear that the failure of the police or Crown prosecutor to consider screening or extrajudicial sanctions does not give rise to a judicial power to stay charges. 
gender or ethnicity. ${ }^{40}$ The narrow judicial authority of a judge to review the Crown's decision to prosecute also arises if there is bad faith; for example, if charges are laid only because the victim of a crime did not receive expected financial compensation from an offender, charges should be stayed as an "abuse of process."

In addition to the formal, narrow judicial power to stay proceedings as an abuse of process, some judges, in appropriate cases, are likely in practice to "suggest" that the Crown prosecutor refer the youth to some form of extrajudicial measures. A judge might, for example, make this type of suggestion at a pretrial conference, which is a meeting held in many jurisdictions between prosecutor, defence counsel and a judge, that typically resolves procedural issues and explores whether the entire case can be resolved without trial. This judicial power of "suggestion" for use of extrajudicial measures is not legally binding, but may be quite influential with some prosecutors. It would seem most appropriate for a judge to make this type of suggestion in situations where the prosecutor or police appear to lack familiarity with youth justice court processes and programs, or where there appears to be a persistent failure by local police or prosecutors to use the provisions of the $Y C J A$ that require consideration of extrajudicial measures. If there has been a failure by the prosecutor or police to deal with an appropriate case by means of extrajudicial measures, the judge might take account of this at the time of sentencing. This might, for example, result in a reprimand or an absolute discharge for a case that the judge thought should have been resolved by extrajudicial measures.

\section{WaRnings and Cautions}

\section{A. Police Warnings and Cautions: Sections 6 and 7}

In Canada, the police have the initial responsibility for investigating suspected offences and deciding whether to commence formal legal proceedings against a person believed to have committed a criminal offence. In most provinces, the police have the authority to commence the proceedings by appearing before a justice of the peace to swear an information (also referred to as "laying charges"). In some provinces, such as British Columbia, a Crown prosecutor screens cases before police proceed to swear an information.

While a youth justice court judge cannot refer a case to an extrajudicial sanctions program. there is a narrow residual discretion in any case for a judge to stay proceedings where compelling the accused to stand trial would contravene "the community's basic sense of decency and fair play and thereby [call] into question the integrity of the [justice] system": $R$. v. $O^{\circ}$ Connor. [1995] 4 S.C.R. 411 at 457 . The abuse of process power is to be exercised only in the "clearest of cases" and might, for example, be invoked if there was a lengthy delay in laying charges after a police investigation, or if a person were tried several times resulting in hung juries and further prosecution seemed "oppressive." There is also a doctrine known as de minimis non curat lex (the law is not concerned with trivialities), which has occasionally been invoked by Canadian judges to dismiss charges, as. for example. in drug cases where a small quantity of drugs are discovered. But it would appear that, since $R$. v. T. $(V)$, supra note 35 . this doctrine cannot be used in youth justice court to deal with cases that might have been diverted. See D. Stuart, Canadian Criminal Law, 4th ed. (Scarborough: Carswell, 2001) at 594-99.

$4 \quad$ R. v. Thore, [2001] B.C.J. No. 720 (S.C.), online: QL (BCJ). 
In all provinces, the police have a critical role in deciding whether to begin a process that could lead to a formal response to a suspected crime. For adolescents who are apprehended for relatively minor offences, a police officer may decide not to invoke the formal processes of court or even of an extrajudicial sanctions program. The officer may decide that a youth should be dealt with informally, sometimes by warning the youth about not committing further offences. This practice, commonly known as "police screening," was widely employed when the $J D A$ was in force, at a time when there were few formal programs for diversion from the juvenile court. ${ }^{42}$ Police screening was especially common with delinquents under twelve, but it was used with juveniles of all ages. Under the $J D A$, some police forces kept records of "police cautions" so that they could determine when a youth had "run out of chances."

The practice of police screening reflects the belief that some cases do not warrant the time and effort of formal charging. It also reflects an understanding that the cautioning of a youth by a police officer can be an effective, low-cost way of holding the youth accountable and, in some cases, to arrange for compensation to a victim. Further, the warning that there will be more serious consequences if there are further criminal acts can have a significant deterrent impact with some youths.

The $Y O A$ recognized the value of this police practice, with s. 3(1)(d) acknowledging that "where it is not inconsistent with the protection of society, taking no measures ... should be considered for dealing with young persons." ${ }^{43}$ Indeed, when the YOA was enacted, there was a concern that the introduction of formal alternative measures programs should not result in "net widening": that is, alternative measures programs were intended to be a true alternative to youth court and not a means of dealing formally outside court with youths who would have been informally screened by police under the $J D A$. As discussed above, in some localities, notwithstanding the intent of the drafters of the $Y O A$, the introduction of the $Y O A$ and the establishment of alternative measures programs resulted in police charging youths who, under the $J D A$, would have been dealt with informally by the police. ${ }^{44}$ The police decision to charge under the $Y O A$ rather than simply caution was influenced by the expectation that the youth who was charged with a less serious offence was still likely to be diverted to alternative measures and not dealt with by the youth court.

Most countries make substantially more use of police screening of youthful offenders than Canada. ${ }^{45}$ New Zealand, for example, has policies to encourage officers to caution youths in their homes and to allow the administration of a caution in the

\2 See, e.g., J.M. Gandy, "The Exercise of Discretion by the Police as a Decision-Making Process in the Disposition of Juvenile Offenders" (1970) 8 Osgoode Hall L.J. 329; and Moyer, supra note 8.

1" YOA, supra note 6 [emphasis added].

tt See, e.g. J. Kenewell, N. Bala, \& P. Colfer, "Young Offenders" in R. Barnhorst \& L.C. Johnson, eds., The State of the Child in Ontario (Toronto: Oxford University Press, 1991) 160 at 165; and J. Hackler \& D. Cossins, Police Screening Patterns in Five Western Canadian Cities (Edmonton: Centre for Criminological Research, University of Alberta, 1989).

ts J.P. Hornick \& S. Rodal, The Use of Alternatives to Traditional Youth Court: An International Comparison (Calgary: Canadian Research Institute for Law and the Family, 1995). 
presence of the parents at a police station by a senior officer. Specially trained youth officers are able to arrange for restitution and an apology to a victim or community service work. About three-quarters of the youth offenders with whom the police come into contact in New Zealand are handled by the police without any other formal process. The police keep a record of their cautioning and it is not unusual for a youth to be diverted more than once. About one-eighth of cases are resolved at a family group conference, and only about one-eighth of cases are dealt with in the youth courts. The cases that go to court in New Zealand are only the most serious ones or those where the youth is denying guilt and wants a trial. ${ }^{46}$

It has been recognized that more extensive use of police screening would also be appropriate in Canada, although subject to some important qualifications. To encourage more use of police cautioning, as well as to provide some consistency and regulation of the practice, some provisions of the YCJA make explicit reference to police cautioning. The exercise of discretion by the police not to charge is an important type of extrajudicial measure and, as such, is encouraged by the general statements in ss. 4 and 5. These statutory statements of principle stress the importance of responding outside the court system to adolescent offenders, especially if they have no prior record of offending and the offence does not involve violence. Often a non-court police response is the most effective, most humane, and least expensive way of dealing with an adolescent who has made a mistake. In appropriate cases, an informal, relatively rapid response of a police officer - especially an officer with sensitivity and experience in dealing with youths - can have as much or more impact in terms of deterrence and accountability than a much-delayed, often perfunctory appearance in youth justice court.

Unlike the $Y O A$, which only alluded to police screening in vague terms, ss. 6 and 7 of the $Y C J A$ are specifically directed to the police. Section 6 explicitly states that, before taking steps to begin a formal court process against a youth, a police officer "shall ... consider whether it would be sufficient ... [to] warn the young person, administer a caution ... [or] refer the young person" to a community-based program. ${ }^{47}$ In making a decision not to proceed to court, the officer who deals with a young person believed to have committed a crime is expected to take into account s. 4 , with its presumption that non-violent first offenders should not be charged. More generally, the officer should consider the seriousness of the offence, the prior record and attitude of the youth, and the views of the victim, as well as any policies of the specific police force.

While police officers have an obligation to consider whether to deal with a youth outside the court system, s. 6(2) of the YCJA makes clear that this is an entirely discretionary matter, specifying that the "failure of a police officer" to consider any form of extrajudicial measures "does not invalidate" any subsequent court proceedings

3. G. Maxwell \& A. Morris, "Juvenile Crime and Justice in New Zealand" in N. Bala, J.P. Hornick, \& H. Snyder eds., Juvenile Justice Systems: An International Comparison of Problems and Solutions (Toronto: Thompson Educational Publishing, 2002). 
and is technically not reviewable by a judge. However, if it appears that an officer has failed to consider some form of diversionary measures, the prosecutor may decide to divert the case.

When considering how to respond to a youth suspected of an offence, an officer may have a number of different options, depending on local resources and policies. The least intrusive response is for the officer who first comes in contact with the youth to personally warn the youth not to commit any further offences. The YCJA refers to both the police "warning" in s. 6 and the police "caution" in s. 7. There is no legal difference between a "warning" and "caution," but the "caution" is seen as a more formal response that might, for example, be administered at the police station by a senior officer. Even so, it is still administered by the police without any need for charges to be laid and without any sanctions being imposed. The police warning is to be administered informally by the officer handling the case, although it may include the officer meeting with the parents of a youth. The officer may contact the parents, telling them that their child is believed to have committed an offence. The officer may discuss with the parents whether the offending behaviour is related to other problems that might be assisted by a social agency or doctor, or whether the child's school or church might be able to provide help, leaving it for the parents to decide what help to seek. The officer might arrange for a simple apology to a victim or a return of stolen property. If there is to be much interaction between the offender and victim, a referral to an extrajudicial sanctions program is likely appropriate.

Police forces generally now have policies that require a report of a police warning or caution to be recorded, so that if there is a repetition of offending behaviour, there may be a more intrusive response. There is understandably a desire to have a good record kept of prior police warnings, though in practice this may not always occur, and in particular if a youth has been involved in cases served by different police forces, there may not be adequate sharing of information. While this may result in some youths receiving "more chances than they deserve," the granting of "second chances" is not inconsistent with the $Y C J A$.

In Australia and some other countries, programs have been established that allow a senior officer at the police station to meet with the youth and parents to discuss offending behaviour and administer a more formal caution against repetition of offending. Section 7 of the $Y C J A$ encourages provincial governments to have programs and policies for police cautioning, perhaps modeled on the programs in Australia, with the caution being administered by a specially trained officer who is sensitive to youth and aware of community resources. A caution may involve the sending of a "caution letter" by the police or prosecutor to the youth and parents warning of the consequences of further offending. The cautioning process may also involve a voluntary referral for further help from a social agency or community resource.

In Canada, if the youth's behaviour or situation seems more serious, or there is a victim who expects or would benefit from some type of restitution or meeting with the offender, the youth may be referred by the police to a formal extrajudicial sanctions program. In most provinces the police can refer a youth directly to such programs 
without charging the youth. In some provinces a referral to an extrajudicial sanctions program can only be made by a Crown prosecutor after charges have been laid, although the views of the police officer who has been handling the case are usually considered by the prosecutor in deciding whether to make a referral.

The value of the police warning and caution provisions of the $Y C J A$ for the handling of individual cases will be affected by the polices of local police forces and provincial governments, as well as by the training, knowledge, and sensitivity of individual officers. If the internal management systems of police forces focus on "charge rates," it is unlikely that there will be much screening or diversion. If a police force has specially dedicated and trained officers whose core mandate includes diversion and informal resolution of cases and who are aware of community resources, it is likely that there will be extensive use of these informal responses to youth crime. While the enactment of the $Y C J A$ encourages police forces to reconsider their approaches to youth crime, it does not mandate such change.

\section{B. Crown Cautions and ScReening: Sections 8 and 23}

Section 8 of the $Y C J A$ allows the provincial governments to implement programs to have prosecutors administer cautions to youths instead of starting or continuing judicial proceedings. Prosecutors have always had the authority to discontinue a case, but this type of program would encourage them to exercise this discretion in appropriate cases, after warning the youth against committing further offences. The prosecutor might also meet with the parents or make a referral to a community agency.

Section 23 of the $Y C J A$ allows provincial governments to establish programs to have prosecutors screen youth cases before charges are laid. In appropriate cases, the prosecutor may decide that charges should not be laid; the youth might be referred to a program of extrajudicial sanctions or the prosecutor might decide to personally caution the youth or to send a caution letter. In some jurisdictions, prosecutorial screening of youth charges was a common practice before the $Y C J A$ was in force; s. 23 is intended to encourage this practice. Nonetheless, it is for provincial governments to decide whether to have this type of program. Giving the prosecutor a formal screening role can ensure that the police have complied with any provincial policies about diversion. Further, in cases that may seem a little more contentious, the prosecutor may be more willing than a police officer to take responsibility for deciding not to have a case dealt with by the courts.

Prior to the enactment of the $Y C J A$, it was theoretically possible for a victim who disagreed with the decision of the police or prosecutor to screen or divert a case to commence a "private prosecution" against a youth to bring a case to court. This involved the victim appearing before a justice of the peace to swear an information to commence the proceeding and then appearing in court to prosecute the case. This did not happen frequently under the $Y O A$, but when it did it could be quite intrusive since the victim appeared to have control over the youth's future. This could result in a case which would otherwise have been dealt with informally being dealt with by the courts. It was already a common practice under the $Y O A$ for the Crown prosecutor to review 
private prosecutions, and either take over the prosecution or exercise the Crown discretion to stay the prosecution, which minimized the potential for the abuse of this kind of process. Section 24 of the $Y C J A$ codifies the practice of Crown involvement in youth justice prosecutions, requiring the consent of the provincial Attorney General to any private prosecution of a young person. This should ensure that a private prosecution does not occur in circumstances in which a youth should be diverted from the court system, although the views of the complainant or private prosecutor should be considered by the police and prosecutor when deciding how a case should be handled.

\section{Subsequent USE OF a Caution OR WARning: Section 9}

Decisions by the police or a prosecutor to caution a youth or to refer a youth to a program of extrajudicial sanctions do not require any finding or formal admission of guilt by the youth. Since there is no formal finding or legal admission of guilt, s. 9 of the YCJA provides that the fact that the police or prosecutor has cautioned a youth or has referred a youth to extrajudicial sanctions cannot be used in any proceedings against the youth as proof of guilt in connection with that offence. In any event, if a case is resolved by a warning or caution, or referred to extrajudicial sanctions, it will be rare for the case to be referred to court.

The fact that a youth has participated in a more formal extrajudical sanctions program is treated differently in subsequent legal proceedings from the youth having been warned or cautioned. Section 10(2)(e) requires that as a condition of participation in extrajudicial sanctions the youth must accept responsibility for the offence. If there is a subsequent finding of guilt for another offence in youth justice court, at the sentencing stage the court may be informed of the prior participation in extrajudicial sanctions (or alternative measures), as this may be indicative of the failure of this type of response to have an effect on offending behaviour. The fact of prior participation in extrajudicial sanctions may be taken into account as an aggravating circumstance if there is a subsequent offence.

Prior use of extrajudicial measures is likely to be relevant in considering how any subsequent offending behaviour should be handled. If the youth is later found guilty in court in connection with another offence, then at the sentencing stage the court may receive evidence about the use of extrajudicial sanctions in the two preceding years, ${ }^{48}$ though no reference may be made to a prior police or prosecutorial warning or caution.

Before deciding whether to caution a youth, make a referral to a program of extrajudicial sanctions, or send a case to court, a police officer will usually discuss the offending behaviour with the youth. The fact that the youth acknowledges the offending of extrajudicial measures other than extrajudicial sanctions (i.e., a caution or informal diversion) can only be shared with (a) a police officer or Crown considering whether to again use extrajudicial measures for a later offence; (b) participants in a conference considering whether to use extrajudicial measures; (c) a police officer, Crown or conference participant dealing with the offence in question; or (d) a police officer investigating a later offence. 
behaviour and expresses remorse could be a significant factor in deciding that a formal court response is not required. An admission of guilt by the youth in such a situation is very likely inadmissible in court. If there is any suggestion by the police that they may not proceed with formal charges if the youth confesses or agrees to participate in some type of extrajudicial sanctions program, any statement is likely to be considered induced by "hope of advantage" and, hence, involuntary and inadmissible. Section 10(4) of the $Y C J A$ provides that any statement made by a young person "as a condition of being dealt with by extrajudicial measures is inadmissible" against the youth in any civil or criminal proceedings; this provision would probably be applicable in this situation. Further, the statement is inadmissible if the police have not fully advised the youth of his or her legal rights in accordance with the Charter and s. 146 of the YCJA.

The decision not to divert or screen a charge involves a significant exercise of "low visibility" police or prosecutorial discretion. There is a potential that this discretion may be exercised in a discriminatory fashion. Some research reveals a concern by youth belonging to visible minorities that police are less likely to exercise their discretion not to charge when dealing with minority youth than when dealing with youth not belonging to visible minorities. ${ }^{49}$ Beyond the issue of systemic discrimination, there may be a tendency for officers to "give a break" to youths from "good families," thereby in effect prejudicing youths from disadvantaged backgrounds. The exercise of police and prosecutorial discretion to screen or divert to extrajudicial sanctions should be guided by appropriate policies and training to assure fair and effective application. Further, there should be adequate record-keeping and information-sharing to ensure that youths are not being repeatedly screened by different officers on different occasions.

\section{Youth Justice Committees: Section 18}

To encourage the use of extrajudicial measures and community involvement in responding to youth crime, the $Y C J A$ has provisions authorizing conferences and youth justice committees. While both were used under the $Y O A$, it is expected that their use will increase with the enactment of the YCJA.

Although the manner and extent of their use depends on provincial policies and local initiatives, the federal government is encouraging this type of response to youth crime by providing educational materials, as well as funding support for the operation and evaluation of model committee programs. Section 69 of the $Y O A$ allowed provincial governments to establish local volunteer youth justice committees "to assist ... in any aspect of the administration" of the $Y O A$, or in any programs or services for young offenders. A significant number of these committees were established in different parts of Canada, in particular in Manitoba and in some Aboriginal communities. In each locality the committee had membership drawn from those in the community with an interest in assisting young persons in trouble with the law. These committees had a range of functions, such as monitoring and supporting the administration of the youth justice system, but their most common function was to administer "alternative measures 
programs," the term used in the $Y O A$ for what the $Y C J A$ refers to as "extrajudicial sanctions." To emphasize the continuity in approach to youth justice committees, $s$. 165(4) of the $Y C J A$ stipulates that any youth justice committee established under the $Y O A$ is deemed to continue under the new Act.

Section 18 of the $Y C J A$ is similar to the youth justice committee provision in s. 69 of the YOA, but has added a long list detailing possible functions for youth justice committees. The previous act required that the members of these committees were to serve "without remuneration." While the members of these committees will continue to be drawn from the community, the requirement that all members serve without remuneration is not in the $Y C J A$. This clarifies that, in addition to volunteers, police officers and professionals who work for community agencies or schools may be members. It also allows for possible payment of a person serving in the role of coordinator.

It is expected that youth justice committees will continue to serve an important role in individual cases, especially in situations where extrajudicial measures are being used. A committee may, for example, under s. 19 of the $Y C J A$, accept a referral from the police or a prosecutor to arrange a meeting involving an offender and a victim, and then make a recommendation for an appropriate extrajudicial measure. A committee may also be involved in providing support for victims and assisting in their reconciliation with offenders. A youth justice committee may also have a role in arranging for support or supervision of young offenders in the community, whether referred by a court or as a result of extrajudicial measures.

Section 18(2) of the $Y C J A$ makes clear that youth justice committees may be asked to play a role in monitoring the implementation of the $Y C J A$, advising federal and provincial governments about how to improve the youth justice system, and providing information to the public about the youth justice system. A youth justice committee may also be asked to play a role in co-ordinating the efforts of local child welfare agencies, social agencies, and schools in working with young offenders. Some youth justice committees are also involved in responding to offending by children under twelve, in conjunction with parents, police, and child welfare agencies.

The way in which a youth justice committee operates will depend on the role that it is expected to play. If it is dealing with individual youth, it is important that a committee has appropriate policies and a training program to ensure that volunteers understand their mandate. While the whole group may deal with policy issues, frequently only a subgroup of committee members deals with individual cases.

\section{Youth Justice CONFERENCES: SeCtions 19 AND 41}

Related to s. 18 of the $Y C J A$, which governs youth justice committees, are ss. 19 and 41 , which deal with conferences. While youth justice committees may act as a conference, the two institutions are distinct. The concept of the conference in the YCJA was at least in part inspired by the "family group conference," as developed in New Zealand. The conference concept is also based on the traditional practices of many 
Canadian Aboriginal communities for dealing with offending members. Indeed, in many communities, as well as in many schools and families, there are long traditions of responding to certain types of less serious offending behaviour by having a meeting with the offender, the victim, and others to discuss the behaviour and develop a consensus about a just response. The $Y C J A$ recognizes the flexible concept of the conference as having a role in responding to youth crime.

A "conference" is defined in s. 2 of the $Y C J A$ as "a group of persons who are convened to give advice" concerning a specific young person having difficulty with the law. This definition is broad, so that a "conference" may be used in a range of different ways. Conferences may involve meetings between offenders, victims, and community members, which would typically have a restorative justice focus. While offenders should be held accountable for what they have done through the conference process, this does not necessarily mean that a punishment needs to be imposed. Sometimes a youth will be held accountable by attending a conference, apologizing, undertaking not to reoffend, and perhaps providing some form of compensation to the victim.

The YOA did not have specific provisions for conferences, although in practice in some places they were used, especially in dealing with youth from Aboriginal communities and in regard to alternative measures. Under the $Y O A$, some alternative measures programs operated on a model premised on having offenders, their families, victims (where appropriate and willing to participate), and community members meet together to discuss the offence and develop a mutually acceptable plan. This type of response is one example of the $Y C J A$ concept of the conference.

Though initially used with adult offenders, under the YOA some judges also made use of "sentencing circles" for dealing with Aboriginal young offenders, especially those living on reserves. The judge would invite the offender, members of the offender's family, the victim and supporters, and community members to come to court and share their views about the offence and offender, and perhaps express their views about an appropriate sentence. Often some form of reconciliation between the victim and offender was an objective of this process, although this was not always attainable. The concept of the conference under the $Y C J A$ includes the sentencing circle, although the conference is clearly a broader institution.

Section 19 of the $Y C J A$ provides that a police officer, a provincial director, or a youth justice court judge may convene a conference to provide advice about any decision to be made under the $A c t$. Such a conference might include such professionals as social workers or teachers who have worked with the youth, and perhaps volunteers or respected Elders in an Aboriginal community. Parents, the youth, or a representative of the youth might be involved, though they are not always directly involved in such advisory conferences. There will normally be a discussion about the offence and the youth, with a sharing of perspectives and information. In less serious cases, a conference may advise the police or a prosecutor about whether the youth is suitable for extrajudicial sanctions. If the case involves extrajudicial sanctions, there may be no formal record of the deliberations of a conference, and only a brief record of its conclusion. 
Police forces in Canada are increasingly involved in establishing their own programs of extrajudicial sanctions, with conferences playing an important role in many localities. A growing number of police officers have training in conducting conferences involving offenders, family members, victims, and community members. Youth justice committees and community agencies are also making increasing use of the conference as an aspect of extrajudicial sanctions programs.

A conference may be used in more serious cases to provide advice to a judge about whether to release a youth from detention pending trial, as well as advising at the time of sentencing or sentence review. Section 19 of the YCJA expressly allows a youth justice court judge to refer a case to a community conference to provide advice for any judicial decision that will be made, such as a decision about pretrial release or about sentencing. Since conferences involve members of the community and local agencies, and tend to operate on restorative justice principles, there is a greater likelihood of a conference resulting in a recommendation for a community-based sentence, and hence conferencing is likely to result in less use of custodial sentences.

Under the $Y O A$, some judges combined aspects of community-based conferencing with court-based sentencing and would, for example, refer a youth to a community conference after a finding of guilt and before a youth was sentenced. Established in 1999, the Calgary Community Conferencing program is one of Canada's leading examples of post-adjudication conferencing. It takes referrals from the youth court, usually after a guilty plea, as well as directly from police or school administrators. ${ }^{50}$ A staff member arranges meetings between victims, young offenders, parents, and others. As a result of the conference, the offender is encouraged to make a proposal for some form of restorative-justice-based resolution which may include some form of compensation to the victim, and perhaps community service and some from of counselling. For cases referred by the courts, the conference facilitator sends a report to the court about the conference, including the proposal made and the attitude of the victim to the proposal. The sentencing judge will consider using the restorative proposal and any recommendation from the conference as the basis of the sentence. The Calgary program has dealt with some quite serious cases, including the armed robbery of a convenience store. ${ }^{51}$

The practice of post-adjudication conferencing is encouraged by s. 19 of the YCJA, which allows for a judicial referral to a community agency or professional to arrange a meeting that may result in a recommendation being made to the court about an appropriate sentence. Section 41 reinforces s. 19, making clear that there can be a judicial referral for a community-based conference after a finding of guilt to make a sentencing recommendation to the court. The conference may have a restorative and

See Judge L. Cook-Stanhope, "Red Necks Meet Bleeding Hearts...?" (2000) 24:2 Prov. Judges J. 34; A.J. Calhoun \& D. Borch, "Calgary Community Conferencing: A Collaborative Approach to Conferencing Serious Offences Pre-Disposition," National Judicial Institute Youth Justice Education Seminar, Toronto (13 September 2002); and R. v. R.(A.J.), [2001] A.J. No. 910 (Prov. Ct.), online: QL (AJ).

s) R. v. K.(B.J.), [2000] A.J. No. 988 (Prov. Ct.), online: QL (AJ). 
conciliatory effect on the participants, and can serve an important role in providing the offender with an understanding of the consequences of his or her acts, and in holding the offender accountable to the victim and society.

A judge may also invoke s. 41 to convene and personally preside over a conference. The practice of "circle sentencing," a form of judicially convened conferencing, is becoming a more common way of dealing with both youth and adult offenders, especially in Aboriginal communities. ${ }^{52}$ If a judge presides over a conference to provide advice about sentencing, it will be held as part of the court proceeding under s. 41 of the $Y C J A$. In this situation, the participants in the conference should probably not be considered witnesses who are subject to cross-examination by counsel, although there may be a dialogue involving the judge, lawyers, and members of the conference.

If a conference is presided over by a judge, a record of the proceedings should be kept and may be used by the judge for the purposes of making decisions about the youth. This judicially supervised conference is usually intended to bring the community and the court closer together, and requires trust and co-operation between members of the community and the judiciary. Although s. 41 makes clear that the recommendation of a conference is not binding on the court, in practice judges are generally likely to follow the recommendations of a conference, since these recommendations reflect a consensus of the victim and members of the community.

Youth justice committees and conferences are similar but distinct. Youth justice committees are established in specific communities and have a continuing existence and fixed membership. Committees may deal with individual cases or systemic issues, while conferences deal only with individual cases and have a membership determined to deal with specific cases. The mandate of a youth justice committee may include the convening of conferences about youths from a particular community, perhaps with some or all of the committee members participating in the conferences. The YCJA enables youth justice committees and conferences to play an important role in supplementing the role of the youth courts. However, their actual role ultimately depends on the willingness of provincial governments to implement the provisions of the $Y C J A$ and provide financial support for this type of response to youth offending, and on the interest of community members and justice system professionals to support these nonjudicial methods of responding to youth offending.

An interesting program that involves elements of both conferencing and a youth justice committee has been the Yukon Youth Justice Panel, which was established under the $Y O A^{53}$ and is expected to be continued under the $Y C J A$. The Yukon had one of the highest rates of police charging and use of custody in Canada. The program was established with the aim of reducing use of youth court, pretrial detention, and custody by building better relationships between key agencies and enhancing community supports. In 2000 a Steering Committee was established, including the Chief Judge,

32 See Judge H. Lilles. "Youth Justice Initiatives in the Yukon" (2000) 24:2 Prov. Judges J. 18.

s3 See Judge H. Lilles. Yukon Youth Justice Panel. National Judicial Institute Youth Justice Education Program. Toronto (13 September 2002). 
senior representatives and directors from the police, legal aid, the prosecutor's office, victim services, and various organizations that provide services to young offenders and Aboriginal persons. The Steering Committee sets policies for the program and meets quarterly to review the program, but does not deal with individual cases.

Individual cases are dealt with by the Yukon Youth Justice Panel, which meets weekly to review youth cases where charges have been laid. The members of the Panel include a designated Crown and defence counsel, staff representatives of probation, alternative measures, police, victim services, and various youth and Aboriginal serving organizations. The Panel has a paid co-ordinator who meets with the youth and parents and provides information to the Panel. The Panel discusses individual cases and tries to reach a consensus about an appropriate resolution or referral. The Panel can make referrals to local agencies and to programs that can arrange for a conference between the victim and offender. Some cases are referred directly by the Panel to some form of extrajudicial measures, while others are sent to court with a recommendation that is usually endorsed by Crown and defence counsel. Some cases are referred by the Panel to youth court and then adjourned in youth court and referred back to the Panel or other agencies for further assessment and recommendations before final disposition by the court.

The Yukon Panel has improved co-ordination between agencies and increased available community supports and services for young offenders. For every case considered, there is an emphasis on seeking a community-based or diversionary response. In its first year and a half in operation, the rate of use of pretrial detention in the Yukon was reduced by 50 percent and the rate of secure custody use was reduced by 67 percent.

There are some legitimate concerns about how community-based conferences will function. For example, will victims be willing to participate, and will their interests be adequately protected? Will victims feel intimidated by the presence of the offender or silenced by the presence of his supporters? In some cases, a conference may result in a proposal for a sanction that is harsher than the sentence that a youth justice court might impose. Because of these concerns, s. 19(3) allows the provincial government to establish rules for the operation of community-based conferences, for example, to ensure that its members have some training and that fair procedures are followed and appropriate sanctions are imposed. If introduced by a provincial government, these rules will, for example, govern cases that are referred by the police or Crown prosecutor for extrajudicial sanctions.

Section 19(3) also specifies that any provincial rules that are promulgated do not apply to community conferences dealing with a youth on referral from a judge or to judicially convened conferences. Sections 19 (1) and 41 make clear that a youth justice court judge may refer a matter to a conference to provide the court with a recommendation, or the judge may directly convene and preside over a conference. Since these types of conferences operate under judicial control, direct provincial regulation would not be appropriate. However, even judicially convened conferences 
will be difficult to operate effectively without a level of support from various government-funded agencies, such as probation services and the police.

Section 119(1)(j) allows for the sharing of information about the young person with those involved in the conferencing process. Staff, volunteers, and community members need to be instructed about their obligation to keep this type of information confidential.

\section{EXTRAJUdicial SANCTIONS UNDER THE YCJA}

The process for referring a youth to an extrajudicial sanctions program will vary significantly from one jurisdiction to another, and sometimes between programs within the same province. ${ }^{54}$ In some provinces a youth will be referred to an extrajudicial sanctions program without charges being laid (called a "pre-charge program"), but in others, such as Ontario, charges will have to be laid before a case can be sent to extrajudicial sanctions (a "post-charge program"). Some provinces will use both preand post-charge programs.

In most pre-charge programs, the police refer youths directly to the program, perhaps after some form of consultation with the Crown prosecutor's office, without even commencing a youth justice court proceeding. It is also possible to have a pre-charge program for which referrals are made by the Crown prosecutor as a result of referral after Crown screening of charges. In post-charge programs, a court proceeding is commenced, and the youth is issued a summons or appearance notice for court. If the youth is charged, the youth may be fingerprinted and photographed. Under s. $119(2)$ (a) of the $Y C J A$, if the case is resovled by extrajudicial sanctions, two years from the date that the youth consents to participate in the program, no further use can be made of those records, and the centralized Canadian Police Information Centre records will be destroyed at that time.

With post-charge programs, the youth will generally have a first appearance in court before the Crown prosecutor decides whether the youth should be referred to the program. If the case is referred to an extrajudicial sanctions program, the court case will be adjourned pending a decision about which sanction should be imposed and the charges will be dismissed by the court if the youth satisfactorily completes the program. Generally, the Crown prosecutor will arrange for the formal dismissal of the charges without the youth reappearing. Post-charge programs are more cumbersome. However, when extrajudicial sanctions are not completed, it is easier to bring a case to court if proceedings have already been commenced.

The initial decision about whether to divert a youth from the court system to an extrajudicial sanctions program is to be made by the police or prosecutor. Thus, the support of local police and prosecutors is essential for the success of this type of program. Police officers and prosecutors are most likely to be supportive if they have an understanding of how the program operates and have a good relationship with the 
program administrators. In some communities, police officers may directly operate the extrajudicial sanctions programs, but even in these communities the officers who operate the program need to enlist the support of other officers and satisfy them that this is an appropriate way to hold youth accountable.

Section 10(2)(b) of the $Y C J A$ specifies that the person "who is considering whether to use [an] extrajudicial sanction [program should be] satisfied that it would be appropriate, having regard to the needs of the young person and the interests of society." The making of this decision requires consideration of the threat posed to society by the youth's behaviour, the youth's circumstances, and the effect of the offence on the victim. In practice, the decision to refer will be governed by the provincial or local policy that regulates the exercise of discretion by the prosecutor or police when deciding whether a youth is eligible for extrajudicial sanctions. These policies typically specify that only certain offences are eligible for diversion. However, under the $Y O A$ there was substantial variation among provinces in eligibility policies and criteria, and this is likely to continue under the YCJA.

A common procedure is to have the Crown prosecutor, generally acting with the advice of the police, make the decision about whether to divert a youth to an extrajudicial sanctions program instead of dealing with the case in the courts. In some provinces, the Crown prosecutor may have a report prepared by a probation officer to assist in deciding whether a youth is suitable for extrajudicial sanctions or, as in Quebec, the local child welfare agency may be involved in consulting with the prosecutor. In some places, a pre-charge extrajudicial sanctions program may accept referrals directly from the police without the involvement of the Crown prosecutor's office - for example, the pre-charge program operated by Royal Canadian Mounted Police at Sparwood, British Columbia, involving victim-offender resolution conferences.

There is a duty imposed under s. 10(2)(f) of the YCJA on the Crown prosecutor, or an agent of the Crown (such as a designated police officer), to form the "opinion" that there is "sufficient evidence to proceed with the prosecution of the offence." Section $10(2)(\mathrm{g})$ also specifies that extrajudicial sanctions cannot be used where the "prosecution of the offence is ... in any way barred at law," for example, by the passage of the six-month limitation period for a strictly summary offence. These provisions are intended to prevent "net widening" and ensure that extrajudicial sanctions are not used as a way of responding informally to a case that is "too weak" to take to court. Cases with insufficient evidence for a prosecution should not be dealt with by the justice system at all, although it will sometimes be appropriate for a police officer in such a situation to speak informally with the youth and parents to warn against engaging in criminal behaviour.

The referral to extrajudicial sanctions by the police or prosecutor will involve the transmission to the program operator of documents that explain the nature of the alleged offence and provide some information about the youth to the program operator. A meeting will be arranged between the program operator and the youth. In some localities, responsibility for meeting with the youth and arranging for the supervision of extrajudicial sanctions is given to a community agency with paid staff or volunteers, 
or to a youth justice committee, while in other places government social workers or youth probation staff are responsible. ${ }^{s s}$

Increasingly, police forces in Canada are also being involved in various extrajudicial sanctions programs which may be operated by officers with special training and interest in young offenders. Some police forces, for example, arrange family group conferences as a part of extrajudicial sanctions, and may, as a result of a conference, require restitution for victims. The Australian and New Zealand experience with youth diversion programs involving specially trained police officers has generally been positive; the programs directly involving the police in convening or attending the meeting tend to have high levels of support and use by local police forces. ${ }^{56}$

Aboriginal communities in particular are also establishing extrajudicial sanctions programs and youth justice committees that involve meetings with offenders and their family members, victims, and community members such as respected Elders. This is consistent with Aboriginal principles of traditional justice, which reflect restorative justice ideals and emphasize the importance of restoring relationships within the community; it is also consistent with s. 5 of the YCJA.

Under the $Y O A$, in some provinces the offence criteria for referral of Aboriginal youth to alternative measures were broader than for non-Aboriginal youth, in recognition that there are social, political, and constitutional reasons for dealing with Aboriginal youths outside of the conventional justice system, a system that has clearly failed to deal adequately with Aboriginal offending. ${ }^{57} \mathrm{~A}$ wider offence jurisdiction for extrajudicial sanctions for Aboriginal youth under the $Y C J A$ may also be appropriate. Extrajudicial sanctions programs that give Aboriginal communities greater responsibility for their troubled adolescents have the potential to permit more effective healing-based non-adversarial responses to youthful offending. ${ }^{58}$

If a youth is referred to extrajudicial sanctions, the person or agency responsible for the program meets with the youth to ascertain what response is appropriate, and to ensure that the response is acceptable to the youth. In some localities, the meeting is very informal, with just a youth worker and the young person present.

Section 11 of the $Y C J A$ requires that a parent must be notified, orally or in writing, of any extrajudicial sanction that is imposed, but it is a common practice to involve parents in the process before a decision is made about how to proceed. Normally the meeting will result in the development of a plan that will be recorded in a written agreement; programs generally have forms that help structure these agreements.

Ibid. at 3.

See, e.g., Morris \& Maxwell, supra note 10; and Daly, supra note 10.

The courts have accepted that it does not violate $s .15$ of the Charter to offer alternative measures to Aboriginals in circumstances where others do not have the same opportunity: $R$. v. Willocks (1995), 22 O.R. (3d) 552 (Gen. Div.).

See, e.g., R. Ross, Returning to the Teachings: Exploring Aboriginal Justice (Toronto: Penguin, 1996); and R. Green, Justice in Aboriginal Communities: Sentencing Alternatives (Saskatoon: Purich, 1998). 
Increasingly, programs are being established in Canada that involve victims, parents, and possibly members of the community meeting with the youth and a facilitator to attempt to achieve some form of reconciliation and develop a suitable plan.

Section 5 of the $Y C J A$ makes clear that extrajudicial sanctions programs should encourage the involvement of families of young persons and victims in determining an appropriate response to the offence and that, if possible, this should be a restorative response that repairs the harm caused to the victim and community. However, unlike in the youth justice court, where parents can be required to attend if their presence is necessary or would be in the best interests of their child, ${ }^{59}$ the involvement of parents and victims in any extrajudicial sanctions program is voluntary. Although with appropriate supports and encouragement many parents will be willing to participate in extrajudicial measures, some parents will not be willing to attend.

Section 12 gives a victim the right to request and obtain information about how a youth who has been sent to an extrajudicial sanctions program has been dealt with. This is, however, a minimum requirement and, consistent with ss. 3 and 5 of the $Y C J A$, many extrajudicial sanctions programs are trying to involve victims more actively in the process. It is important for victims to have a sense that justice has been done and, in appropriate cases, to meet with offenders or receive some form of compensation for the harm that they have suffered ${ }^{60}$ It is a common practice to notify the victim before sanctions are imposed and, often, to invite the victim to a meeting with the youth, at which the offence is discussed and an appropriate response developed. While these meetings can provide an important opportunity for victims to feel vindicated and for offenders to gain an appreciation of the effects of their conduct, special care should be taken to respect the needs and fears of victims. Victims should not be pressured into participating, and the meetings must be conducted with sensitivity to ensure that neither the victim nor youth feels intimidated by the experience. If appropriate, extrajudicial sanctions may include some form of restitution, apology, or personal service by the youth to the victim, although there should be a fair and realistic assessment of the youth's ability to make compensation. Youths without financial resources should not be penalized because of their inability to make restitution, while youths from wealthy families should not be able to in effect "buy their way out" by making an inordinately large "payoff" to a victim.

Victim-offender reconciliation may be an object for some extrajudicial sanction meetings (such as when the victim and offender attend the same school) and most programs place some emphasis on restorative justice objectives. Although a meeting may be an important restorative act for some victims, other victims want nothing to do with the offender. When a large corporation is victimized, as often occurs in shoplifting cases, it may be a less appropriate participant as a "victim" engaged in the extrajudicial sanctions. Even in these cases, it is important for a youth to understand that harm has

3." YCJA, supra note 4, s. 27.

(A) See, e.g., K.J. Pate \& D.E. Peachey, "Face-to-Face: Victim-Offender Mediation Under the Young Offenders Act" in J. Hudson, J. Hornick, \& B. Burrows, eds., Justice and the Young Offender in Canada (Toronto: Wall \& Thompson, 1988) 105. 
been done, and a security officer or manager may represent the victim and explain the effects of the crime on society as a whole.

In some cases, it may be desirable to give the youth an opportunity to reflect on and acknowledge the offence by asking him or her to write an essay or prepare a poster on the subject, although account should be taken of the youth's abilities in imposing any requirements for written work. Or it may be appropriate for the youth to do some community service work or make a donation to a charity, to make clear to the youth that offending behaviour harms the whole community.

In cases where there has already been a suitable parental response to the offending behaviour or some form of reparation has been made to the victim before the case comes to extrajudicial sanctions, it may be that no further response is required after a meeting with the program operator.

In some provinces, a common form of extrajudicial measure for minor offences, such as shoplifting, is to have the police or a community youth justice committee send a letter to the parents and youth which records the fact that the youth is believed to have committed an offence, and warns the youth not to commit further offences, and leaves it to the parents to determine an appropriate response. In Manitoba this is called a "parental action letter," while in Alberta and British Columbia it is referred to as a "caution letter." The decision to impose no further sanctions will depend on the nature of the offence and may be influenced by the attitudes of the victim and the youth.

Usually, extrajudicial sanctions are arranged with just one meeting between the youth and others involved in the process. Sometimes more than one meeting is held, for example if the participants feel that there is a need to gather more information, involve others, or consider their position. A plan may be arranged that will involve a reconvening of the group to monitor the youth's progress. In some localities. extrajudicial sanctions programs may make use of a range of responses that are not merely sanctions but that try to address the causes of a youth's offending behaviour.

In some communities programs are directed at certain types of offending behaviour, such as shoplifting. One option may be to require a youth to attend a valuesdevelopment course directed at adolescents with offending problems. This type of course is commonly used in Quebec. In some places, there may be a requirement for a community supervisor or mentor, or a referral may be made for some form of counselling. Such counselling might be provided by a therapist, doctor, or community agency. In an Aboriginal community, a youth may be required to enter into a relationship with a respected Elder as a mentor.

A response recommending therapy or counselling is premised on the belief that some offending behaviour is a symptom of an emotional, social, behavioral, or substanceabuse problem. Responding to a youth's underlying problems is most likely to prevent further offending, as well as being generally beneficial to the youth. Some extrajudicial sanctions programs, however, are not permitted to make a referral to counselling a requirement of participation; these programs take a "non-interventionist approach," 
believing that a referral to counselling is too intrusive a response to the relatively minor charges that they deal with and should only be imposed by a court. ${ }^{61}$ Even if the policies that govern an extrajudicial sanctions program preclude imposition of conditions of counselling, the staff or volunteers who meet with a youth may, in appropriate cases, make a referral to a youth or parents for further counselling, treatment, or support, explaining that this is a suggestion for help they may wish to obtain, and is not a condition of participation.

While most youths who are sent to extrajudicial sanctions programs in Canada have not committed serious offences and are not likely to reoffend, there is a minority who may pose a future threat to society. If such youth do not have their needs addressed at this early stage of involvement with the youth justice system, they will likely commit subsequent, more serious offences. Extrajudicial sanctions programs that respond to the problems of youths at risk are consistent with s. 3(1)(a)(i) of the YCJA, which recognizes the importance of "addressing the circumstances underlying a young person's offending behaviour." This suggests that counselling or treatment conditions may be appropriate options for some of the more troubled youths referred to extrajudicial sanctions programs.

\section{ROLE AND RIGHTS OF YOUTHS}

An extrajudicial sanctions program can offer a youth the opportunity for an expeditious, informal response to an alleged violation of the law. If the case is resolved by extrajudicial sanctions, the youth and parents will generally feel less intimidated than if the case goes to court, and they are likely to participate more fully in any discussions about the offence and their circumstances than in the more formal, adversarial court setting. So it is not surprising that research reveals that parents and youth may be more likely to perceive themselves as having been treated fairly in a diversion program than in court. ${ }^{62}$ For the youth and parents, diversion avoids the stigma of having a youth justice court record. The parents may also encourage their child to choose extrajudicial sanctions, since there is no need to incur the expense of having a lawyer and there may be no need for parents to take time away from work or other activities to attend court. As a result, there may be considerable pressure on a youth to participate in extrajudicial sanctions. There is the potential for a fairly intrusive response to a quite minor offence with extrajudicial sanctions, or even for participation by a youth who is not guilty of any offence. While the $Y C J A$ has provisions that are intended to minimize the risk of an abuse of the rights of a youth, there are fewer protections if a youth goes to an extrajudicial sanctions program than if the youth goes to court.

Extrajudicial sanctions programs are not designed to be "informal courts." Under s. $10(2)$ (e) of the $Y C J A$, extrajudicial sanctions may be used "only if ... the young person accepts responsibility for the act ... that forms the basis of the offence that he or she

1.1 This is, for example, the official policy in Ontario. Counselling is not considered "an appropriate measure," although program workers provide "information about counselling and a [voluntary] referral might be appropriate as part of the negotiation process." Ontario, supra note 28 at 15.

i: See, e.g., Morton \& West, supra note 11 at 211 . 
is alleged to have committed." ${ }^{13}$ Typically this provision is satisfied at the meeting between the youth and program operator to develop a plan of extrajudicial sanctions. The youth will be asked to discuss the circumstances of the alleged offence, explaining the nature of his or her participation in it. Often a youth will make a full admission of guilt, but s. 10(2)(e) technically does not require that the youth accept full legal guilt for the specific offence alleged. Sometimes a youth may question some aspect of the specific charge or police report, but accepts that he or she was in some way "responsible" for an illegal act.

While s. 10(2)(e) does not require a full legal admission of guilt, it at least requires an acknowledgement by the youth of involvement in the offence and an acceptance of moral responsibility for the offence alleged. A youth who "denies [his or her] participation or involvement" or who expresses the wish to be dealt with in youth justice court cannot be dealt with by an extrajudicial sanctions program. ${ }^{64}$ If this occurs, the program operator should refer the case to the Crown or police so that the matter can be dealt with in youth justice court. A trial to determine whether or not a youth is guilty can be conducted only in youth justice court.

Section $10(2)(d)$ requires that a youth must be advised of the right to legal representation and given a reasonable opportunity to consult with counsel before consenting to participate in extrajudicial sanctions. Most programs ensure that at an early stage of the extrajudicial sanctions process the youth accepts responsibility for the offence alleged, agrees to participate, and is aware of the right to consult a lawyer. However, unlike the situation for youths who are dealt with in youth justice court for whom s. 25(4) of the $Y C J A$ provides access to legal representation if the youth is unable to afford to pay for a lawyer - there is no statutory provision dealing with access to legal services for youths referred to extrajudicial sanctions. Some youths do consult a lawyer before agreeing to participate. If the program is post-charge, the youth may, for example, have an opportunity to have a brief meeting with duty counsel at youth justice court before the case is referred to extrajudicial sanctions. A few programs arrange for duty counsel to be present to meet with the youth prior to the youth accepting responsibility and agreeing to participate, but in times of increasing fiscal restraint, it is difficult to obtain a commitment from legal aid authorities to fund this type of assistance. There are concerns that some youths may in effect waive their legal rights, perhaps because of a "desire to get things over with" or because of parental pressure, without fully appreciating their position. This may happen even if a youth has not committed the act alleged or would have a valid defence to the allegations.

Whether or not there is successful completion of the extrajudicial sanctions plan, $\mathbf{s}$. 10(4) of the YCJA specifies that no statement or confession made by the youth "accepting responsibility" for the offence as a condition for being dealt with by extrajudicial measures may be used in any later civil or criminal court proceedings. Section 10(4) is intended to reassure youths and their advisers, as well as to encourage youths to accept responsibility and participate in extrajudicial sanctions. The provision 
may also reflect a concern that there may be cases in which there is the potential for a youth to feel coerced into "accepting responsibility" in order to gain access to extrajudicial sanctions, despite the fact that the youth is not actually guilty. Even without s. 10(4), in many cases there would be an argument that a statement made by a youth as a condition of participation in alternative measures was induced by a "hope of advantage" (the dismissal or staying of charges) and would thus be involuntary and inadmissible in any subsequent prosecution.

Under s. $10(2)(c)$ a youth must also agree to the specific extrajudicial sanction that is developed for him or her. If the youth objects that the plan is too onerous and the appropriateness of the sanction is not resolved by discussion, then the case must be referred to court. In some cases, the plan developed in extrajudicial sanctions may be more onerous or intrusive than the sentence which a youth justice court judge would impose, but the youth without legal assistance may not be aware of the discrepancy and may erroneously believe that any alternative measures plan is less than the sanction a court would impose. One Crown prosecutor, John Pearson, commented on the problems that can arise from the lack of access to legal assistance in connection with alternative measures under the YOA. These comments remain relevant to the $Y C J A$ :

If parents and young persons have difficulty appreciating the need for counsel when they are going through the court system, how likely is it that they will recognize the need when a "non-judicial" resolution is being proposed? Once alternative measures are invoked, the young person is dealt with by a system that has none of the mechanisms required in order for legal representation to be effective. A well-meaning diversion committee, from which there is no appeal, determines society's response to the young person's criminal conduct. The philosophy behind the juvenile-court movement is played out on another stage. ${ }^{65}$

Pearson expressed concern that in some respects the "diversion movement" is similar to the informal paternalistic court of the $J D A$, where state actions that were intended to promote the best interests of adolescents could result in a much more intrusive response than the offence warranted.

It would be desirable to ensure that all youths who are referred to extrajudicial sanctions have actually had access to legal advice before waiving their right to go to court, especially since the youth's participation may be held against him or her if there were a later prosecution for another offence. However, given the less serious nature of the offences and the fact that only community-based sanctions can be imposed, the drafters of the YCJA (and the YOA) did not give youths referred to extrajudicial sanctions the statutory right to counsel.

With scarce resources, legal aid plans generally do not provide access to legal services for youths referred to these programs. Even parents with financial means may feel reluctant to pay a lawyer for a case that they believe is being dealt with informally. 
Those who administer extrajudicial sanctions programs should be aware of the potential for violations of rights, and in particular of the potential that a youth may feel coerced by parents or others into accepting responsibility for an offence that he or she did not actually commit, as well as for the possibility that an unduly onerous plan may be imposed on a youth.

\section{Consequences of Participation in Extrajudicial Sanctions}

If a young person agrees to participate and successfully completes the extrajudicial sanction plan agreed to, the case cannot proceed to court. Section 10(5)(a) of the $Y C J A$ specifies that if the case is brought to youth justice court, the judge must dismiss the charges. If an extrajudicial sanction plan is developed and agreed to, but the youth does not fully complete it, there may be another meeting between the youth and the program administrator to discuss any problems that the youth may be having. The program administrator may decide to refer a youth who has not fully complied with the sanction plan to the police or prosecutor, who may bring the case to court. Non-completion is most likely to result in referral to court if the offence was more serious and the noncompletion was wilful and substantial. Under section 10(5)(b) the judge has a discretion where there is only partial completion of extrajudicial sanctions. If the prosecution is considered to be unfair, the judge may dismiss the charge or take account of the partially completed plan when sentencing the youth. The judge should consider how much of the plan was completed, the reasons the plan was not fully carried out, and whether the extrajudicial sanctions have had an effect on the youth.

Section $119(2)$ (a) of the $Y C J A$ provides for a two-year "period of access" for records relating to extrajudicial sanctions, running from the date that a youth consents to the specific sanction. During the two-year period of access, s. 119(1) lists individuals who can obtain access to the records of an extrajudicial sanctions program, including the youth, the victim, and youth corrections or probation staff. If within the two-year period a youth is charged with and convicted of an offence, then s. 40(2)(d)(iv) of the YCJA specifies that a pre-sentence report prepared to assist the judge in sentencing the youth for that later offence shall include "the history of alternative measures under [the YOA] ... or extrajudicial sanctions used to deal with the young person and the response of the young person to those measures or sanctions."

In theory, it might be argued that prior participation in an extrajudicial sanctions (or alternative measures) plan should not be weighted as heavily against a youth as a prior formal youth justice court finding, since there has been no judicial finding of guilt. However, at a subsequent sentencing hearing, the prior involvement is a "part of the history of the person being sentenced" and may demonstrate that a more intrusive or punitive response may be appropriate for that individual. ${ }^{66}$ Prior participation in extrajudicial sanctions is generally a negative factor at any subsequent sentencing, even if the participation arose out of a pre-charge program. Prior participation makes it unlikely that a court will merely reprimand the youth or impose an absolute discharge. The possibility of later use of a record of extrajudicial sanctions emphasizes the need 
to ensure that those youths who waive their right to go to youth justice court are truly accepting responsibility for their acts and are aware of the consequences of participation.

Some extrajudicial sanctions programs, especially those that are community-based, have a policy of actually destroying a youth's record of participation two years after the youth consented to participation in the program. While no use is to be made of the record after two years, program operators and government agencies are not technically obliged to destroy the records. After two years, however, no use may be made of any records kept in regard to an offence sent to extrajudicial sanctions. Also, after two years the Canadian Police Information Centre is obliged to destroy any of its records relating to the offence and the youth, as well as the fingerprints and photographs of the youth, assuming there are no further offences in that period. ${ }^{67}$

If a police force has records, including photographs or fingerprints, relating to a youth who has been sent to extrajudicial sanctions who is not convicted of any further offences in the two-year period, the force should not make use of these records after that period, although it is not obliged to physically destroy or delete its records. After two years, many police forces will, on request, retrieve and destroy records relating to a youth who was sent to extrajudicial sanctions and has had a conviction-free period.

\section{Conclusion: The Future of Youth Diversion}

Under the YOA, there was substantial variation in the use of police screening, and alternative measures differed in different provinces, but on the whole Canada made far more use of the formal youth court processes to respond to adolescent offending than did other countries, and less use of various diversionary practices. Canada's extensive reliance on a court-based response to youth offending was both expensive and associated with a high rate of use of youth custody. Experience in other countries clearly indicates that Canada can extend the use of various diversionary programs, including making more extensive use of police screening and cautioning, as well as other community-based programs, without increasing the risk of reoffending. Indeed, some of the international experience suggests that diversionary programs that involve victims and offenders and have some "restorative justice" components may have lower recidivism rates than court-based responses for comparable groups of young offenders. $^{68}$

Various types of diversionary schemes represent a socially useful and cost-effective response to many situations of youth offending. The $Y C J A$ and related supportive federal funding initiatives are intended to significantly increase the use of various diversionary measures, including police or prosecutorial screening and community-based extrajudicial programs. An expeditious, informal response may be preferable to a delayed, formal adversarial court experience for many adolescents, parents, and victims. Indeed, diversion programs are also starting to be established for adult offenders in

6.8 See, e.g., Morris \& Maxwell, supra note 10; and Daly, supra note 10. 
Canada. ${ }^{69}$ There is still, however, surprisingly little research, particularly in Canada, on whether use of various types of diversionary schemes can actually reduce the risk of reoffending. Clearly, this question merits study.

One might expect that the effectiveness of extrajudicial measures in terms of reducing recidivism would depend on the nature of the program and the types of cases dealt with, as well as on whether the program has good links to counselling and community supports that can assist youths at serious risk of reoffending in dealing with their problems. Some of those involved in operating diversionary programs claim that programs that have higher levels of victim involvement are more likely to be effective, both in engaging offenders and in reducing recidivism. Conversely, it seems that noninvolvement of victims may reduce the impact of the diversionary process on the young offender and hence reduce the effectiveness of this type of program. ${ }^{70}$ Research from other jurisdictions also suggests that, while victims whose cases have gone through diversion express higher levels of satisfaction than those whose cases are dealt with in court, victims are not as satisfied as offenders or parents with their experiences in diversion programs. ${ }^{71}$

While various types of youth diversion programs can make some use of volunteers and provide a less expensive response to adolescent offending than sending a youth to court, effective programs require appropriate funding. These programs are most likely to be effective if they have trained competent staff, with enough time to meet with victims and offenders before a conference is held, and to monitor and follow up with a youth after a diversionary decision is made.

Clearly it will be important to monitor different diversionary programs to learn which types of programs, if any, are effective at reducing recidivism and whether there are problems with the abuse of the rights of offenders or disregard for the needs of victims. ${ }^{72}$

There will always be a role for a formal court-based response for those adolescents who commit more serious offences or who are not responsive to informal intervention. There is also an important role for the court system in protecting legal rights. There is also, however, substantial scope in Canada for the greater use of various diversionary responses to youth crime, and the $Y C J A$ should encourage a significant increase in their use.

Criminal Code, R.S.C. 1985, c. C-46, s. 717, enacted as S.C. 1995, c. 22, s. 6. 2001) at 13-15, online: <www.fulbright.org.nz/voices/axford/docs/schmidd.pdf>.

7 Daly, supra note 10 at 78.

"2 The federal government is conducting some research into the effectiveness of the pilot extrajudicial sanctions programs that it is funding. 